
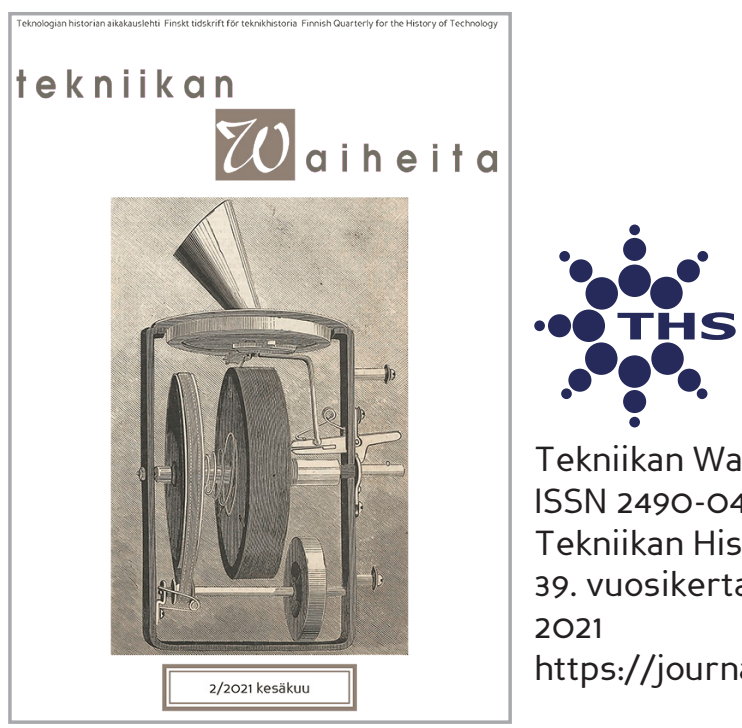

Tekniikan Waiheita

ISSN 2490-0443

Tekniikan Historian Seura ry.

39. vuosikerta: 2

2021

https://journal.fi/tekniikanwaiheita

Monialaisen yhtiön johtamisen haaste: Tampella yhtiö vuodesta 1958 vuoteen 1995

Jouko Wacklin

To cite this article: Jouko Wacklin, "Monialaisen yhtiön johtamisen haaste: Tampella yhtiö vuodesta 1958 vuoteen 1995" Tekniikan Waiheita 39, no. 2 (2021): 106-115. https://doi. org/10.33355/tw.109431

To link to this article: https://doi.org/10.33355/tw.109431 


\title{
Monialaisen yhtiön johtamisen haaste: Tampella yhtiö vuodesta 1958 vuoteen 1995
}

\author{
Jouko Wacklin, Jyväskylän yliopisto
}

Tampella oli yksi maan suurimmista suomalaisista ryhmittymistä ja yksityisistä yrityksistä, jolla oli hyvä rahoitus ja suhteet hallitukseen. Yrityksen historia muodostaa jännittävän kehityspolun, jossa kilpailuympäristön muutokset loivat jatkuvasti johtamishaasteita organisaation ja tekniikan kontekstissa. Tampella toimi useilla toimialoilla, joista osa liittyi läheisesti toisiinsa ja osa ei. Merkittävimmät toimialat olivat metsäteollisuus, metalliteollisuus ja sen konepajat, tekstiili-, sähkö- ja muoviteollisuus. Edellisen kaltainen hajautettu liiketoiminta oli tyypillistä suomalaisille metsäteollisuusyrityksille 1980-luvulle saakka.

Tampellan varhainen kehitys loi perustan sen seuraaville vuosikymmenille, yli sadalle vuodelle. Vuonna 1844 lakimies Idman sekä kartanonomistajat Ramsay ja Idestam perustivat Tampereelle ruukin, joka teki jo varhain rautakauppaa Venäjän kanssa. Gustaf Wasastjerna perusti monialayritys Tampellan vuonna 1856 yhdistämällä Idmanin masuunin, valimon ja sahan. Uusi hallituksen puheenjohtaja oli pastori ja opettaja Alfred Kihlman, joka laajensi konepajan tuotevalikoimaa edelleen laivoista vesiturbiineihin ja puuhiomakoneisiin. Sotakorvausten onnistunut toimittaminen Neuvostoliitolle tuki maiden bilateraalikauppaa, joka myös edesauttoi merkittävästi Tampellan konepajan teknistä kehitystä. Tampellan toiminnalle oli tärkeää valtion tuki, Tampereen maantieteellinen sijainti sekä muiden toimialojen kehitys. Varsinkin sähkön kehittyminen energialähteenä oli tärkeä asia suomalaiselle teollisuudelle.

Sellu- ja paperiteollisuudessa ensimmäiset suomalaiset tasoviira-paperikoneet käynnistettiin Tampereella vuonna 1842. Tampellan uudet innovaatiot perustuivat usein kansallisten klustereiden yhteistyöhön, kuten hiomakoneiden valmistus vuonna 1873. Seuraavana vuonna alkoi Tampellan kiinnostus metsätalouteen, jolloin se perusti mekaanisen sellukartonkiyhdistyksen Papermill Oy:n kanssa. 1880-luvun alkupuolella Tampereen Puuhiomo integroitui Tammerfors Linne- och Jern-Manufaktur Aktiebolaget -yritykseen, joka perusti pahvikartonkia ja kemiallista puukuitua tuottavat kartonkitehtaat jo vuonna 1872. Vuodesta 1886 lähtien yhtiö osti hiomakoneita, perusti Papermill Oy:n, osti metsäalueita ja investoi yhtiön ensimmäiseen jatkuvatoimiseen kartonkikoneeseen Inkeroisissa, jonne myös yhtiön kartonkiosaaminen keskitettiin.

Toimitusjohtaja Wolter Ramsayn johdolla yhtiö keskittyi yhä enemmän metsäteollisuuteen ja sen laitteisiin, kuten vaneripuristimiin, talteenottokattiloihin, vetureihin ja vesivoimalaitteisiin. Tampellan teknologiaa kehitettiin useilla eri tavoilla, kuten esimerkiksi 1930-luvun puolivälissä Tampellan, Maskin \& Bro, Varkauden ja Karhulan konepajojen perustetun TAMAVAKA-nimisen yhteisyrityksen avulla. Saman vuosikymmenen aikana Tampellaan saatiin kansainvälistä teknologiaa perustamalla yhteisyrityksiä, esimerkiksi amerikkalaisen konepaja Black-Clawsonin kanssa, sekä matkustamalla konetoimittaja Voith Heidenheimin vieraaksi Saksaan.

Yhtiö laajensi eri liiketoimintojaan vähitellen. Vuonna 1938 Tampella vastasi kasvavaan painopapereiden markkinakysyntään aloittamalla sanomalehtipaperin tuotannon, ja vuonna 1952 semikemiallisen massan tuotannon Anjalankoskella. Seuraavana vuonna yhtiö laajensi eri liiketoimintojaan edelleen aloittamalla kaivosteollisuuden porauslaitteiden valmistuksen. 
1960-luvulla Tampellan kolme tärkeintä toimialaa olivat metsä-, metalli- ja tekstiiliteollisuus. Yhtiön strategiset painopisteet perustuivat uusiin teknologisiin innovaatioihin kuten sulfiittimassaan, integroitujen tuotantoprosessien mekanisointiin ja sanomalehtipaperin- ja kartongin tuotantoon. Uudet investoinnit, kuten Heinola Flutingin aaltopahvi kartonkikone 1961 ja Inkeroisten kartonkikone vuonna 1965, sai johdon ymmärtämään, että Tampellan merkittävä kilpailuetu oli konepajatoiminnan sekä paperi-, sellu- ja kartonkituotantoyksiköiden välinen yhteistyö. Samanaikaisesti Tampellan sellu- ja paperiliiketoiminnan tekemien suorien investointien aikana toteutettiin lukuisia yritysostoja kuten Espanola SA ja Latexteollisuus $\mathrm{Oy}$.

Vuosien 1961 ja 1980 välillä yhtiö keskittyi intensiiviseen liiketoiminnan hajauttamiseen, ympäristökysymyksiin, sulfiittiselluloosan muuttamiseen sulfaattiselluloosaksi, sekä kierrätetyn sanomalehtipaperin ja kartonkien tuotantoon.

Konglomeraatti Tampellan elinkaaren aikana Suomen- ja kansainvälinen taloustilanne heijastui yhtiön tulokseen johtuen yhtiön kansainvälisestä liiketoiminnasta ja siitä, että yrityksen rahoitus perustui pääasiassa ulkomaanvelkaan. 1860-luvun jälkeen suomalaisia puutuotteita myytiin pääasiassa Keski- ja Länsi-Eurooppaan tukeutuen liberaaleihin taloussääntöihin ja omaan valuuttaan. Paperimyynti keskittyi Neuvostoliittoon varsinkin sen jälkeen, kun paperitehtaat korvasivat massan perusraaka-aineen rätin puukuidulla.

Tampella ei ollut ensimmäinen toimija Suomessa, mutta se oli yksi pioneereista. Sen kehityspolku oli hyvin samanlainen kuin muiden vastaavien suomalaisten yrityksien sekä kronologisesti että strategisesti. Kyseisessä kehityksessä Suomen hallituksella oli merkittävä rooli, joka 1960-luvulta lähtien investoi tieteeseen ja teknologiaan uuden tekniikan omaksumiseksi ja hyödyntämiseksi. Näin varmistettiin yrityksien työvoiman ja koulutetun väestön saatavuus. Erityisen tärkeitä tekijöitä Tampellan liiketoiminnalle olivat kansallisen metsäteollisuuden intensiiviset teknologiainvestoinnit, keskuspankin suotuisa teollisuuden korkopolitiikka ja kansalliset metsätalouden rahoitusohjelmat (MERA) hallituksen, metsäteollisuusyritysten ja metsänomistajien välisen rahoituksen varmistamiseksi.

Suomalaisilla Enso-Gutzeitilla ja Kymi Oy: llä oli monia yhtäläisyyksiä Tampellan kanssa, kuten kansainvälinen liiketoiminta, monipuolinen liiketoimintarakenne. Nämä yritykset edustivat suomalaista metsäteollisuutta ja olivat merkittävän liikevaihdon omaavia suuryrityksiä, kuten kuvassa esitetään.

Vastaavasti Tampellan samankaltaisuus Enso-Gutzeitin ja Kymi Oy:n kanssa voidaan todeta kyseisten yhtiöiden tuottavuuden kehityksestä, joka parani koko ajanjakson ajan. Yksityiskohtana voidaan todeta, että ainoastaan vuosien 1958 ja 1967 välisenä aikana Tampellan tuottavuus oli parempi kuin Kymi Oy: ssä ja Enso-Gutzeitissa. Vuonna 1974, Tampellan henkilöstömäärä oli 8967, minkä jälkeen koko yhtiön henkilöstöä vähennettiin, mutta konepajan ja metsäteollisuuden henkilöstöä lisättiin. Kaiken kaikkiaan konepajan henkilöstö määrä lisääntyi vuoteen 1989 ja metsäyksikön vuoteen 1990 saakka.

Konglomeraatti Tampellan ylimmän johdon haasteet olivat merkittäviä. Ensimmäinen haaste muodostuu siitä, että yhtiön ylin johto edusti samanaikaisesti sekä ostajaa että laitetoimittajaa. Tämä aiheutti ristiriidan siitä, minkä liiketoimintayksikön liikevoitto on tärkeintä ja kuka lopulta tekee päätöksen eri liiketoiminta yksiköiden priorisoinnista. 
Kuva 1. Tampellan emoyhtiön, Enso-Gutzeitin ja Kymi Oy:n liikevaihto (Def. 1995) vuosina 1958-1995.

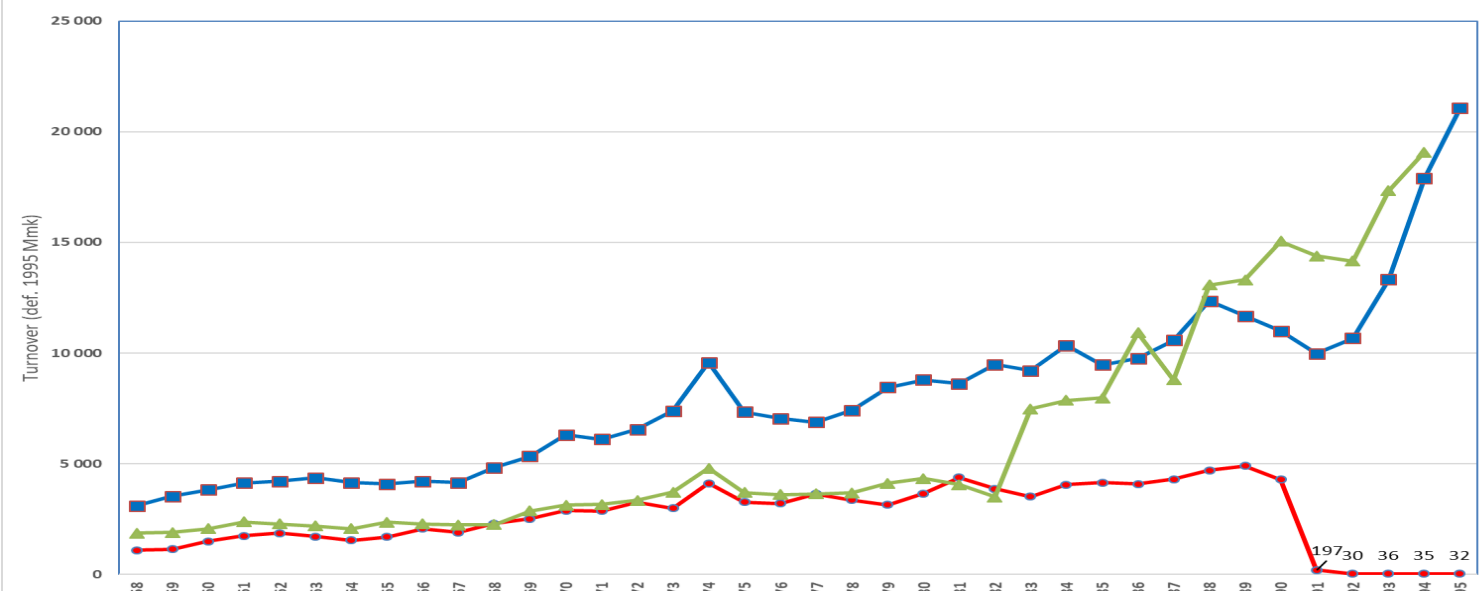

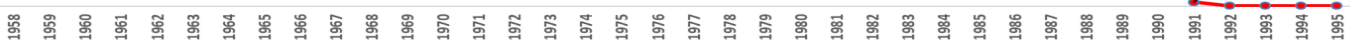

Lähteet: Tampellan, Enso-Gutzeitin ja Kymi Oy:n vuosikertomukset vuosina 1958-1995.

Kuva 2. Emoyhtiö Tampellan työntekijämäärä ja tuottavuus (Def. 1995), Enso-Gutzeit ja Kymi Oy:n tuottavuus (Def. 1995) laskettuna liikevaihto työntekijämäärää kohden vuosina 1958-1995.

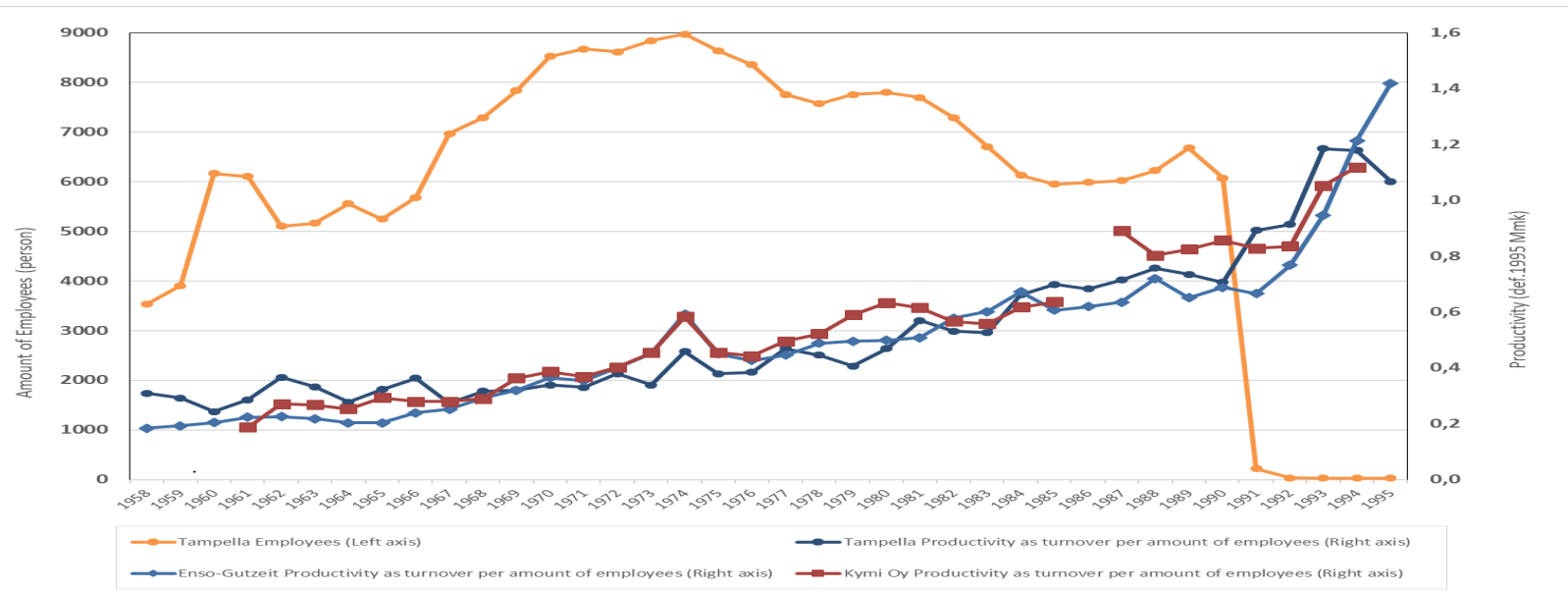

Lähteet: Tampellan, Enso-Gutzeitin ja Kymi Oy:n vuosikertomukset vuosina 1958-1995. 
Kuva 3. Ilmiö - ylimmän johdon haasteet.

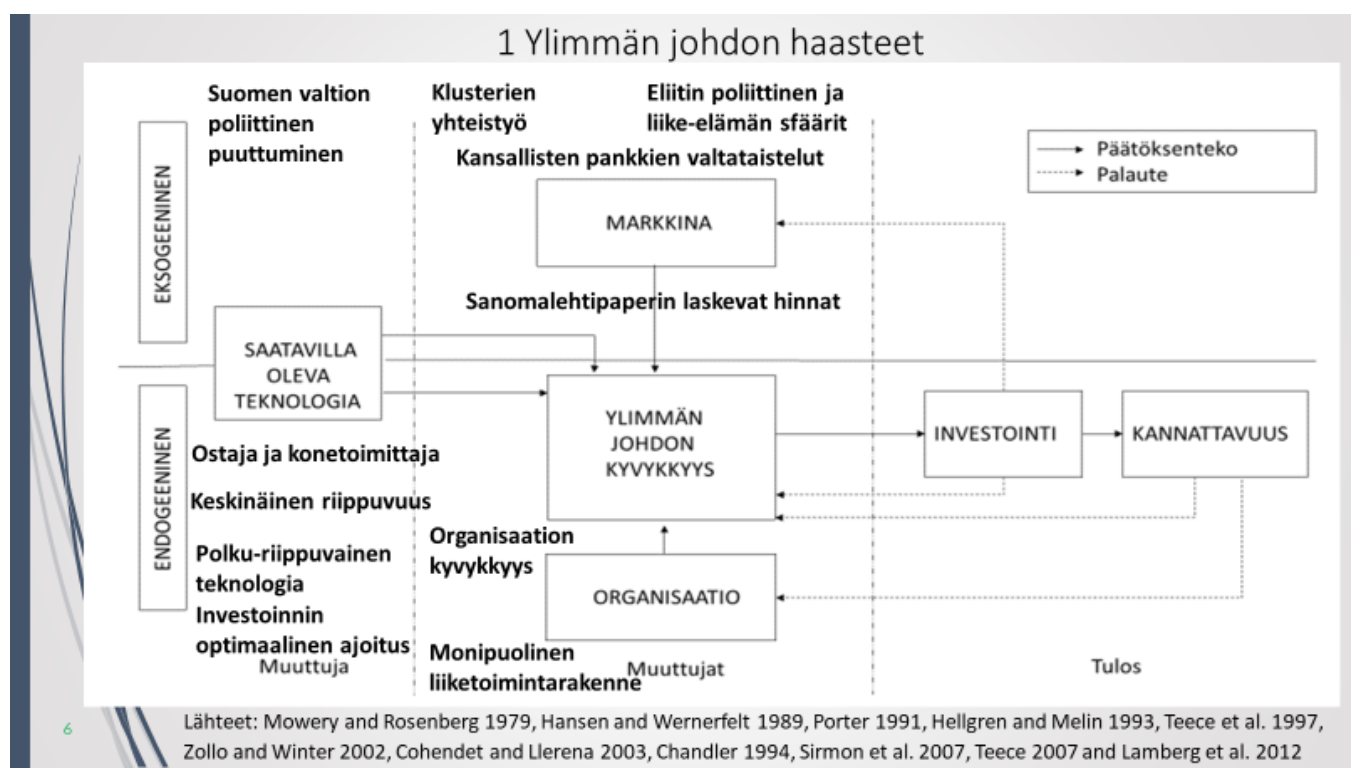

Tampellassa paperi- ja kartonkituottajien tekninen osaaminen perustui merkittävästi yhtiön sisäisen konepajansa tietoihin ja taitoihin varsinkin uuden teknologian käyttöönotossa. Tämä riippuvuus lisääntyi huomattavasti vuosien varrella johtuen yhtiön pääkonttoriin keskitetystä päätöksenteosta investointien kontekstissa. Tämä konepajan ja paperiteollisuuden tuotantolaitoksien välinen riippuvuus loi organisatorisen haasteen tiedon siirrossa ja teknologian ylläpidossa.

Konepajan johtaminen vaikutti osaltaan ylimmän johdon investointipäätöksiin, joka myös aiheutti yhtiölle merkittävän teknologisen polkuriippuvuus taakan. Lisäksi kyseinen johtaminen aiheutti paperi- ja kartonki liiketoimintayksiköiden kehityksen jähmettymisen niin kauan kuin yrityksen paperi- ja kartonkiteknologian osaaminen olivat riippuvaisia sisäisestä konepajasta. Esimerkiksi Inkeroinen ei tehnyt ajoissa merkittäviä investointeja kapeisiin kartonkikoneisiinsa.

Lisäksi uusien paperi-ja kartonkikoneiden myyntimahdollisuudet ulkopuolisille asiakkaille vähenivät johtuen konekonseptien rajallisuudesta erilaisten paperi- ja kartonkilajien suhteen sekä tarjottujen paperi-ja kartonkikoneiden alhaisemmasta mitoituskapasiteeteista verrattuna Tampellan konepajan kansainvälisiin kilpailijoihin.

Yksi Tampellan johdon päätöksenteon haasteista oli metsäyksikön toteuttamien investointien ajoitus, koska metsäteollisuus investoi heikon markkinakysynnän aikana, kun taas konepaja investointien ajoitus on päinvastainen.

Merkittävä asia on myös se, että vaikutusvaltaisten suomalaisten yksilöiden ja Suomen valtion poliittinen puuttuminen vaikuttivat Tampellan johdon päätöksentekoon ja jopa liiketoimintaan. Esimerkiksi 1980-luvulla vaihtui kolmen toimitusjohtajaa ja neljän hallituksen puheenjohtajaa, mikä haastoi yrityksen organisaation johtuen uudesta johtamiskulttuurista 
ja pääkonttorin keskitetystä toiminnasta. Lisäksi avainhenkilöiden nimeämiskäytäntö heijastaa ajan henkeä, jolloin ylimmän johdon nimityksillä pyrittiin vaikuttamaan voimakkaammin sekä kansallisiin poliittisiin suhteisiin että julkiseen mielipiteeseen verrattuna ammattimaisen johtajan nimeämisessä.

Tampellan johtajien haastetta lisäsi massa- ja paperiteollisuuden investointien luonne, joka käsitti pääomavaltaisia, polkuriippuvaisia ja yleensä monimutkaisia sosiaalisia ja poliittisia konteksteja. Esimerkiksi Eurocan Kitimat -hanke oli Suomen hallituksen erityissuojelussa, joten Tampellan johdon motivaatiot olivat sekä kaupallisia uusien myyntimahdollisuuksien toivossa, että poliittisia toivoen hallituksen tuen hyödyntämistä.

Tampella on erinomainen esimerkki useiden muuttujien vuorovaikutuksesta, koska yrityksen teknologinen kehitys perustui kansallisten klustereiden, ylimmän johdon johtamiseen ja keskijohdon toimintaan. Sodan jälkeisenä aikana Suomen metsäklusterin jäsenet saivat liiketoiminnallisia hyötyjä Suomen valtion toiminnalla, joka teki esimerkiksi poliittisia järjestelyjä Neuvostoliiton kanssa ja lisäsi kansallisten instituutioiden teknistä kehitystä. Vuosikymmenien ajan Tampellan metsäliiketoimintayksiköt keskittivät myynnin Finnpapiin, mikä laajensi yksiköiden myyntimahdollisuuksia. Metsäteollisuuden kansallisen konepajatoiminnan kannalta tarkasteltuna kyseiset klusteritoiminnot johtivat yksittäisten yritysten, kuten Valmetin, menestykseen ja toisten, kuten Tampellan, tuhoutumiseen.

Tampellan jatkuva velkaantuminen mahdollisti pankeille yrityksen omistajuuden ja myöhemmin myös hallinnan. Lainan kertyminen johtui pääasiassa ylimmän johdon päätöksistä, jotka mahdollisti kansallisten rahoituslaitosten löysä rahoituspolitiikka Suomen metsäteollisuudelle. Näin kansallisten pankkien aggressiiviset strategiset toimet muuttivat useiden suomalaisten yritysten, kuten Tampellan, omistajuutta. Esimerkiksi yhtiön uusi omistaja SKOP 1980-luvun alkupuolella määräsi välittömästi intensiivisiä investointeja, joiden seurauksena yhtiön pääoman vaihto ja omavaraisuusaste romahtivat tyydyttävästä heikkoon. Ensisijainen syy Tampellan konkurssiin oli, että siitä tuli SKOP:in ja Yhdyspankin valtataistelun uhri, kun ne pyrkivät laajentamaan omistustaan suomalaisissa teollisuusyrityksissä 1980-luvun lopulla.

1980-luvulla Tampellan johdon päätökset sanomalehtipaperin tuotannon laajentamisesta olivat vähintäänkin outoja. Markkinat eivät olleet houkuttelevia sanomalehtien ylikapasiteetin takia, ja sanomalehtipaperien hinnat olivat laskeneet jo vuodesta 1958 lukuun ottamatta joitakin yksittäisiä vuosia. Lisäksi Tampellan kilpailijat olivat jo rakentamassa sanomalehtipaperi kapasiteettia.

Vuosien 1961 ja 1980 välillä yhtiö keskittyi intensiiviseen liiketoiminnan hajauttamiseen, jonka seurauksena sen johtaminen muodostui haastavaksi päätöksenteon ja velan suhteen. Yrityksen taloudellista tilannetta heikensi myös yrityksen liiketoiminnan hajauttaminen, joka sitoi huomattavan määrän operatiivisia pääomia johtuen erityisesti metsä- ja metalliteollisuuden laajentamisesta ja kehittämisestä. Yrityksen alkuvuosina myös tekstiiliteollisuudella oli merkittävä rooli. On selvää, että yhtiön vahva keskittyminen metsä- ja metalliteollisuuteen muodosti yhden Tampellan tragedioista - kyseiset toimialat olivat liian erilaisia johtamisen ja toimintojen näkökulmasta. Molemmat liiketoiminnot tarvitsivat suuren määrän pääomaa johtuen metsäteollisuuden liiketoiminnan raskaista teknologia investoinneista ja konepajan asiakasluotoista.

Yrityksen endogeenisesta näkökulmasta tarkasteltuna ylimmän johdon organisaatiokyvykkyys oli rajallinen, koska he eivät pääsääntöisesti tulkinneet tai hyödyntäneet tietoja suhdannevaihteluista, markkinoista ja hinnoista, vaikka kyseinen informaatio pitäisi aina olla olennainen tekijä uusien investointien päätöksenteossa. 
Tampellan teknologisen kehityksen merkittävä tekijä oli vuonna 1969 allekirjoitettu TVW-sopimus Valmetin ja Wärtsilän kanssa. Se rajoitti ensisijaisesti yrityksen konepajan teknistä kehitystä, mutta myös määritteli paperi- ja kartonkituotantoyksiköiden portfolion perustuen paperi- ja kartonkikoneiden saatavilla oleviin konsepteihin. Samanaikaisesti Tampellan toimialat, joilla ei ollut vastaavia sopimuksia, menestyivät kuten kaivos- ja energia-alojen liiketoiminnat.

Vuosien ajan yrityksen ylimmässä johdossa ei tehty merkittäviä päätöksiä, jotka olisivat muuttaneet yrityksen strategioita. Sen sijaan ylin johto teki monia päätöksiä organisaation toiminnoista, osaamisesta ja resurssien määrästä. Nämä olivat tärkeitä, mutta toissijaisia yrityksen selviytymisen kannalta. Johtoa pyrki parantamaan organisaation toimivuutta kaikissa Tampellan yksiköissä, kuten analyysien tulokset osoittavat. Ylin johto oli kyvykäs tuottamaan ajoittain korkeata liikevaihtoa, mutta sen kyvykkyys hallita taloutta ja luoda jatkuvasti kannattavaa liiketoimintaa oli heikkoa johtuen organisaation kognitiivisesta rajoittuneisuudesta, rutiineista ja kyvyttömyydestä oppia menneisyydestä.

Yrityksen elinkaarta voidaan selittää "alaspäin suuntautuvaksi spiraaliksi". Tämä perustuu siihen tosiasiaan, että ylin johto ajautui päättämättömyyteen, jolloin johtajat eivät tehneet tai eivät saaneet tehdä merkittäviä päätöksiä yrityksen strategiasta tai kriittisistä ongelmista, kuten yrityksen velasta ja klusteripohjaisesta yhteistyöstä. Yrityksen ylimmän johdon olisi pitänyt keskittyä merkittäviin epäkohtiin jo 1970-luvulla, sen sijaan että toisti samoja toissijaisia päätöksiä. Vasta kun yrityksen taloudellinen tilanne oli vakava ja kansalliset instituutiot tekivät rahoitukseen liittyviä muutoksia Suomessa, yrityksen ylin johto päätti luopua liiketoiminnan hajauttamisesta, samoin kuten tekivät monet muutkin suomalaiset metsäyhtiöt, kuten Enso-Gutzeit ja Kymi Oy. Yrityksen ylimmän johdon olisi pitänyt luopua liiketoiminnan hajauttamisesta jatkuvan velkaantumisen ja heikon liikevoiton perusteella.

Toinen keskeinen syy yrityksen jähmettymiseen oli se, että ylin johto ei hyödyntänyt käytettävissä olevaa sisäistä ja ulkoista tietoa oppiakseen aikaisemmista päätöksistä. Seurauksena olivat haitallinen klusteritoiminta, velan hallinnan puute, hyvin myöhäinen siirtyminen sanomalehtipapereista ja voimapapereista korkeamman arvon tuottaviin paperin ja kartongin lopputuotteisiin, ja konepajan teknologisen kehityksen jähmettyminen. Tämä osoittaa ylimmän johdon tietynasteista itseään vahvistavaa käyttäytymistä, joka voi aiheuttaa merkittäviä taloudellisia menetyksiä. 
Kuva 4. Ilmiö - syöksykierre ja päättämättömyys.

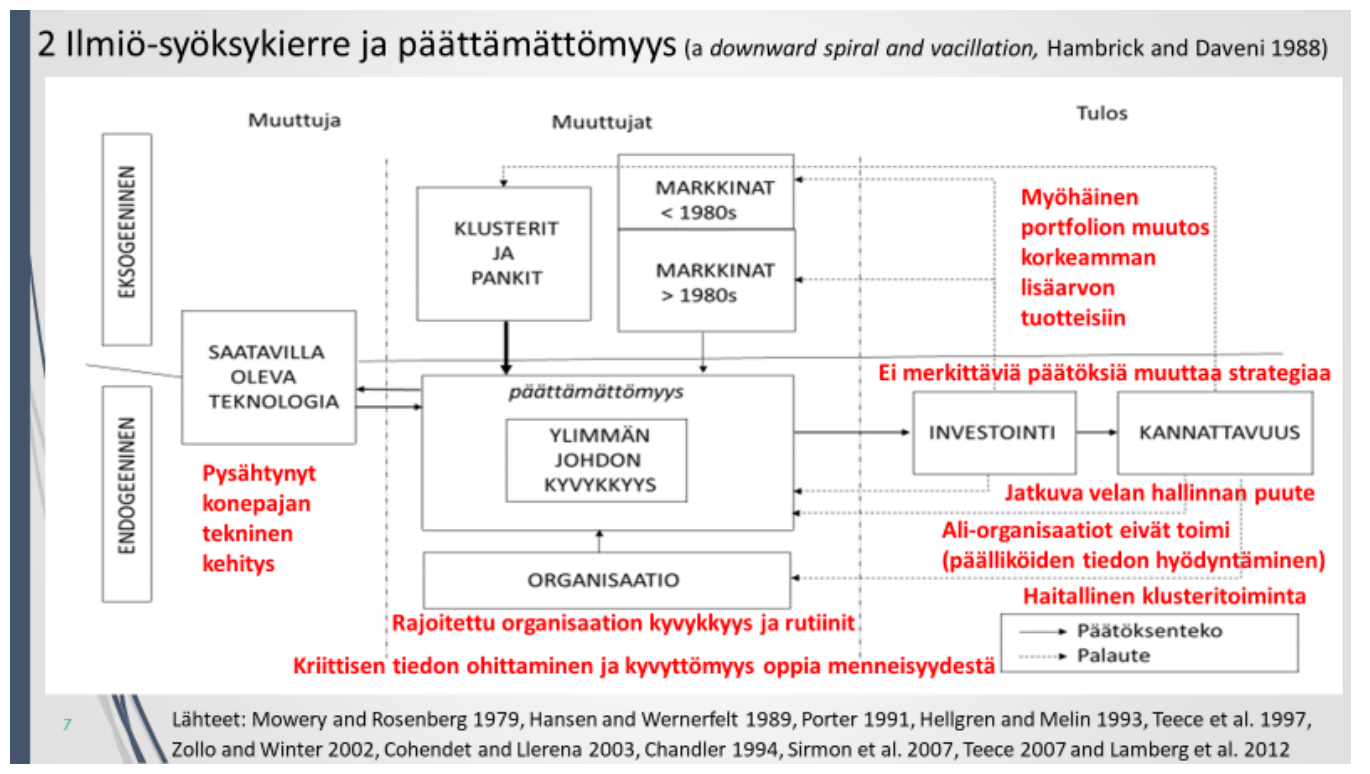

Vastaavasti ylin johto ei huomioinut keskijohdon osaamista strategisessa päätöksenteossaan. Tämä on ilmeistä, koska yrityksen investointi- ja operatiiviset suoritukset perustuivat ensisijaisesti keskijohdon osaamiseen ja vasta toiseksi, ylimmän johdon kyvykkyyteen. Tämä viittaa yrityskulttuurin puutteeseen tukea ylimmän johdon päätöksentekoa investointien ja strategian kontekstissa. Tämän seurauksena johdon ymmärrystä ja liiketoiminnan realismin tunnistamista heikensi organisaation dynaamisen kyvykkyyden puute, joka perustui keski- ja ylimmän johdon heikkoon vuorovaikutukseen yhtiön eri liiketoimintayksiköiden kotimaisissa ja ulkomaisissa sisaryhtiöissä, sekä yrityksen pääkonttorissa.

Kuten kuvassa 5 esitetään, Tampellan nettotulos oli erittäin heikko. Vuosien 1958 ja 1970 välillä tulos oli positiivinen, mutta heikko. 1970- ja 1980-luvut edustivat yrityksen selviytymistaistelua vuosi toisensa jälkeen. Vasta 1980-luvun lopulla yritys teki hyvän tuloksen, mutta se oli liian myöhäistä. Tampellan nettotulos oli huomattavasti pienempi kuin EnsoGutzeit:n tai Kymi Oy:n.

Tämän väitöskirjan kontribuutio ovat seuraavia: Tämä väitöskirja osoittaa, että yrityksen ylimmän johdon organisatoriset valmiudet ovat kriittinen tekijä yrityksen pitkän aikavälin kannattavan toiminnan varmistamiseksi dynaamisen kyvykkyysteorian ja johtavan yrityksen perusteellisen yksittäistapaustutkimuksen perusteella. Huolimatta yhtiön suuresta liikevaihdosta, kansainvälisestä asiakaskunnasta ja merkittävästä sosiaalisesta asemasta, yrityksen jatkuvuus on merkittävässä vaarassa, mikäli yrityksen strategisia ja operatiivisia ongelmia ei poisteta riittävän nopeasti. Ylimmän johdon kyky tehdä päätöksiä perustuu teknologian hallinnan ja luovuuden, organisaatiokäyttäytymisen ja markkinoiden dynamiikan ymmärtämiseen kokonaisuuteen. Nämä ovat kriittisiä tekijöitä liiketoimintamahdollisuuksien tunnistamisessa ja kannattavan liiketoiminnan luomisessa. 
Kuva 5. Tampellan emoyhtiö ja holding yhtiö, Enso-Gutzeit and Kymi Oy netto tulos (Def. 1995) vuosina 1958 ja 1995.

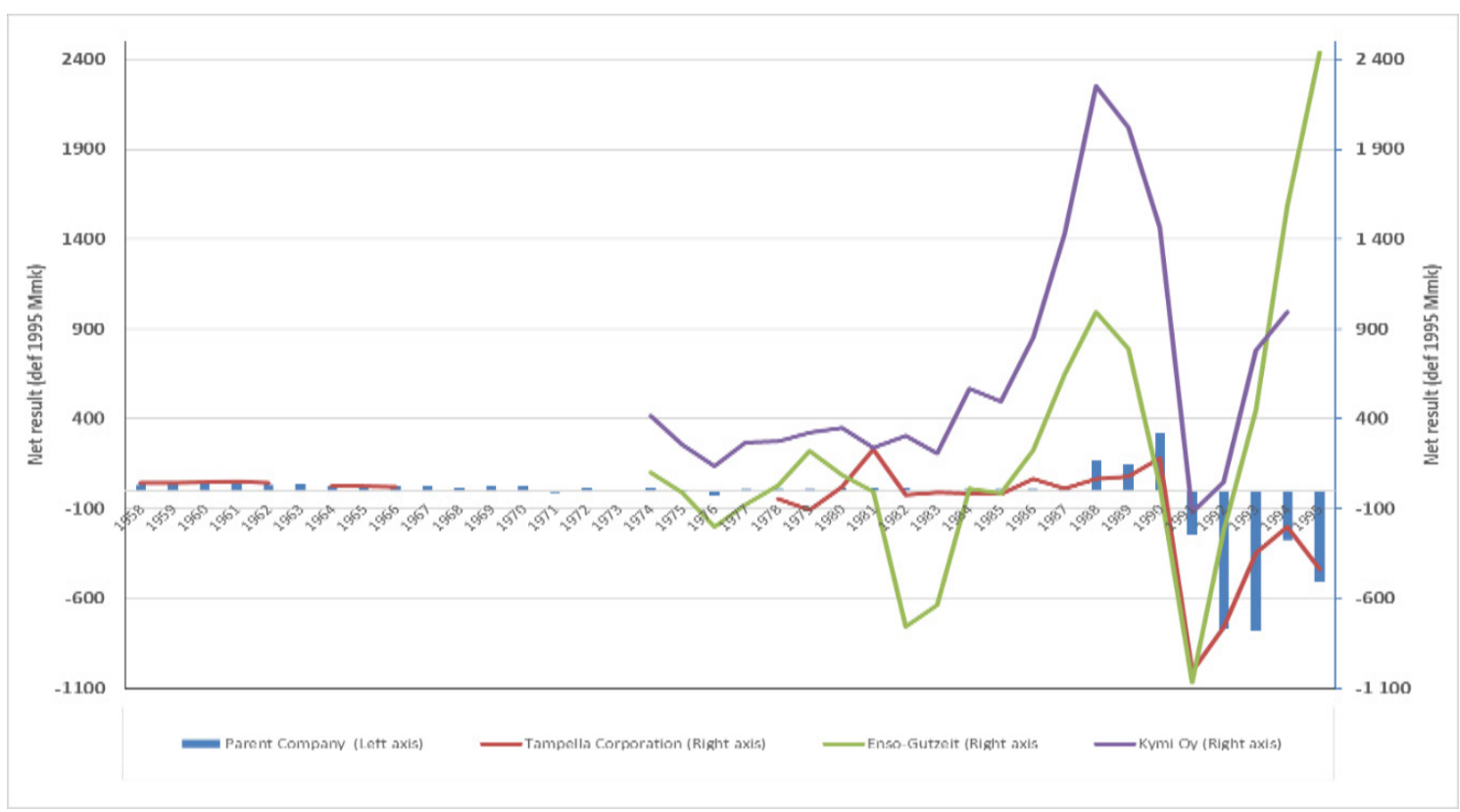

Lähteet: Tampellan, Enso-Gutzeitin ja Kymi Oy:n vuosikertomukset vuosina 1958-1995.

Tässä tutkimuksessa selvitettiin dynaamisen kyvykkyysteorian perusteella, kuinka ja missä olosuhteissa ylimmän johdon kapasiteetin ja tuotantolaitostason osaamisen välinen ero esiintyy ja mitä vaikutuksia sillä on yrityksen suorituskykyyn. Käytännössä tämä tarkoittaa sitä, että yrityksen strategioilla ja perustavanlaatuisilla päätöksillä ei ole merkitystä, mikäli organisaatio ei toimi ja kehitä sisäisiä toimintojaan ylimmän johdon organisatoristen valmiuksien perusteella. Alfred Chandlerin (1992) mukaan kyseiset organisaation ydinosaamiset perustuvat organisaation käyttämien rutiinien hierarkiaan, joka edelleen perustuu organisaatiokulttuuriin ja jotka muodostavat yhden organisaation ydinosaamisen kriittisistä tekijöistä.

Organisaatiokyvykkyyden analysointi on erittäin haastava tutkimusaihe johtuen kyvykkyystutkimukseen liittyvistä käsitteellisistä vaikeuksista. Määritän organisaatiokyvykkyyden siten, että se sisältää dynaamisen kyvykkyyden esimiesten asenteiden, oppimislähtöisen kulttuurin, johtajien työkokemusten ja saatavilla olevan markkinatiedon suhteen. Varsinkin massa- ja paperiteollisuudessa johtajien kyvykkyys tunnistaa liiketoimintaympäristön muutoksia on välttämätöntä yrityksen pitkän aikavälin selviytymiselle, koska kriittisimmät teknologiapäätökset ovat merkittävästi polkuriippuvaisia ja eivät ole itseohjautuvia.

Tämän väitöskirjan toinen kontribuutio on se, että yksittäisen tapauksen perusteellinen analyysi osoittaa yrityksen ylimmän johdon kyvykkyyden merkityksen yrityksen ydinliiketoiminnan, teknologian ja organisaation ymmärtämisessä. Ymmärtämällä ja oppimalla yritys pystyy selviytymään. Teknologian näkökulmasta se tarkoittaa, että teknologia on integroita- 
va yrityksen strategiaan kilpailuetujen säilyttämiseksi ja samalla on huolehdittava siitä, että aikaisemmat investoinnit eivät rajoita tulevia. Organisaation näkökulmasta se tarkoittaa motivoituneiden ja sitoutuneiden työntekijöiden jatkuvaa tiedon omaksumista ja oppimista.

Kolmas kontribuutio osoittaa sen tosiasian, että yrityksen kassavirran hallinta on yksi kriittisimmistä menestymisen tai epäonnistumisen tekijöistä, jonka määrittelen perustuvan ylimmän johdon kyvykkyyteen.

Akateemisesta näkökulmasta tarkasteltuna, tämä väitöskirja laajentaa yrityshistorian teoreettista kehystä ja viittaa harvoin käytettyyn lähestymistapaan yrityshistorian, ja toisaalta organisaatioteorioiden ja strategian väliseen vuoropuheluun. Liiketoimintahistorian näkökulmasta tämä väitöskirja keskittyy yrityksen todelliseen toimintaan, joka perustuu organisaation tietoon ja kyvykkyyteen, kun taas useat liiketalouden historioitsijat asettavat etusijalle tutkimuksessa organisaation monitieteisen rakenteen syntymisen ja leviämisen kuten Chandler 1982.

Lisäksi tässä väitöskirjassa keskitytään teollisuushistoriaan ja teollisuustutkimukseen, jossa korostetaan selluloosa- ja paperiteollisuuden ominaisuuksia, mukaan lukien metsäklusterit, ja niiden vaikutusta yrityksen kannattavuuteen tekniikan, markkinoiden ja niiden yleisen dynamiikan yhteydessä. Verrattuna massa- ja paperiteollisuuden moniin makrotason globaaleihin vertailututkimuksiin (kuten Lamberg et al. 2012), tässä tutkimuksessa korostetaan tutkijan teollisuuden tietämystä, mikä mahdollistaa erittäin yksityiskohtaisen tehdastason tutkimuksen markkinoiden, teknologian ja organisaation kontekstissa.

1990-luvulta lähtien, Suomessa jatkuu paperiteollisuuden murros, joka tiedostetaan pääsääntöisesti tehtaiden sulkemisilla, koneiden muutosinvestoinneilla tai yritysjärjestelyillä. Tässä kansallisessa murhenäytelmässä koen tärkeäksi lisätä yleisön tietoisuutta niistä todellisista tekijöistä, mitkä aiheuttavat kyseisen muutostarpeen. Tämä väitöskirja lisää yleistä tietämystä selluloosa- ja paperiteollisuuden nykyisistä haasteista, mitkä liittyvät käynnissäoleviin julkisiin ja osittain poliittisiin keskusteluihin tehtaiden sulkemisista Suomessa. Esimerkiksi elokuussa 2020 UPM-Kymmene ilmoitti Kaipolan tehtaan sulkemisesta ja Maye-Melnhof Group ilmoitti kaksi päivää sitten ostavansa KotkaMills Group'n.

Lisäksi tätä väitöskirjaa voidaan hyödyntää yrityksen ylimmän johdon koulutuksessa, koska se osoittaa liiketoiminnan ja tekniikan samanaikaisen johtamisen haasteellisuuden, jota ei voi suoraan opettaa koulussa. Kyseinen johtopäätös perustuu kolmeen tärkeään analyysitulokseen: Ensinnäkin tämä väitöskirja osoittaa, että yrityksen onnistunut johtaminen on erittäin vaikeaa, mikäli sen oligopolistisen kilpailun toimintaympäristö tehdään liian haastavaksi sisäisellä ja kansallisella päätöksenteolla. Toiseksi siinä yksilöidään ylimmän johdon kriittisimmät roolit, jotka ovat kassavirran hallinta, liiketoiminta mahdollisuuksien tunnistaminen ja reagoiminen liiketoimintaympäristön muutoksiin. Edellä mainittu jäsennelty markkinatieto on hyödynnettävä yhtiön pitkän aikavälin liiketoimintastrategiassa integroituna käytettävissä olevaan teknologiaan. Voidaan todeta, että kriittinen tekijä on johdon kyvykkyys hallita organisaatiota, tunnistaa liiketoiminnan mahdollisuudet ja ymmärtää edistyksellisen teknologian merkitys. Edellä mainittu tarkoittaa sitä, että kolmantena analyysi tuloksena, perustuen ylimmän johdon kyvykkyyteen, yrityksen organisaatio kulttuuri vaikuttaa merkittävästi sen menestykseen. 